\title{
Beyond Dystopian Education in a Neoliberal Society
}

\author{
Henry A. Giroux
}

Public education and higher education are under assault by a host of religious, economic, ideological, and political fundamentalists. This is true of the United States, but it is also increasingly true elsewhere. In US public schools, the most serious attack is being waged by advocates of neoliberalism whose reform efforts focus narrowly on high-stakes testing, traditional texts, and memorization drills. At the heart of this approach is an aggressive attempt to disinvest in public schools, replace them with charter schools, and remove state and federal governments completely from public education in order to allow education to be organized and administered by market-driven forces.[1] Left unchecked, this movement would turn schools into "simply another corporate asset bundled in credit default swaps" and valued only for its rate of exchange on the open market.[2]

At the same time as public schools face such pressures, a full-fledged assault is being waged on higher education across North America, Australia and New Zealand, the United Kingdom, and other European countries. While the nature of the assault varies in each country, there is a common set of assumptions and practices driving the transformation of higher education into an adjunct of corporate power and values. The effects of the assault are not hard to discern. Universities are being defunded; tuition fees are skyrocketing; faculty salaries are shrinking as workloads are increasing; and part-time instructors are being used as a subaltern class of migrant laborers. In addition, class sizes are ballooning; the curriculum is being instrumentalized and stripped of liberal values; research is largely valued for its ability to produce profits; administrative staff is depleted; governance has been handed over to paragons of corporate culture; and valuable services are being curtailed.

The neoliberal paradigm driving these attacks on public and higher education disdains democracy and views public and higher education as a toxic public sphere that poses a threat to corporate values, ideology, and power. Since the 1950s, colleges and universities have been seen by many to be democratic public spheres dedicated to teaching students to think critically, take imaginative risks, learn how to be moral witnesses, and procure the skills that enable one to connect to others in ways that strengthened the democratic polity. It is for these very reasons that higher education is increasingly under attack by the concentrated forces of neoliberalism. Self-confident critical citizens are viewed as abhorrent by conservatives who remember the campus turmoil of the sixties. Citizens who take their responsibility to democracy seriously now pose a dire threat to corporate power. Unsurprisingly, these same individuals daily face the suspicion of the new corporate university that appears willing to conceive of faculty only as entrepreneurs, students only as customers, and education only as a mode of training.[3]

Welcome to the dystopian world of corporate education in which learning how to think, be informed by public values, and become engaged critical citizens are viewed as a failure rather than a mark of success. Instead of producing "a generation of leaders worthy of the challenges," [4] the dystopian mission of public and higher education is to produce robots, technocrats, and compliant workers. There is more than a backlash at work in these assaults on public and higher education: there is a sustained effort to dismantle education as a pillar of democracy, public values, critical thought, social responsibility, and civic courage. Put more bluntly, the dystopian shadow that has fallen on public and higher education reveals the dark side of a counterrevolution that bespeaks not only an unfettered mode of corporate sovereignty but the emergence of an updated form of authoritarianism. During the Cold War, US officials never let us forget that authoritarian countries put their intellectuals into prison. While political 
imprisonment is not yet pervasive in the US or other capitalist democracies, the majority of critical intellectuals today are destined for conformity, if not poverty if they work in the academy. Too many academics fear the threat of being fired or denied tenure for being too critical, and an overwhelming number of them are relegated from the beginning to an intolerable state of dire financial distress and existential impoverishment.

Education within the last three decades has diminished rapidly in its capacities to educate young people to be reflective, critical, and socially engaged agents. Despite all attempts to degrade the value and purpose of education, the notion of education as the primary register of the larger culture persists. Yet, under a neoliberal regime, the utopian possibilities formerly associated with public and higher education as a public good capable of promoting social equality and supporting democracy have become too dangerous for the apostles of neoliberalism. Critical thought and the imaginings of a better world present a direct threat to a neoliberal paradigm in which the future must always replicate the present in an endless circle in which capital and the identities that legitimate it merge with each other into what might be called a dead zone. This dystopian impulse thrives on producing myriad forms of violence_encompassing both the symbolic and the structural_as part of a broader attempt to define education in purely instrumental, privatized, and anti-intellectual terms. It is precisely this replacement of educated hope with an aggressive dystopian project that now characterizes the current assault on public and higher education in various parts of the globe extending from the United States and the United Kingdom to Greece and Spain.

In light of this dystopian attempt to remove education from any notion of critique, dialogue, and empowerment, it would be an understatement to suggest that there is something very wrong with American public and higher education. For a start, this counterrevolution is giving rise to the commercialization of education, punitive evaluation schemes, harsh disciplinary measures, and the ongoing deskilling of many teachers that together are reducing many excellent educators to the debased status of technicians and security personnel. Additionally, as more and more wealth is distributed to the richest Americans and corporations, states are drained of resources and are shifting the burden of such deficits on to public schools and other vital public services. With 40 percent of wealth going to the top 1 percent, public services are drying up from lack of revenue and more and more young people find themselves locked out of the dream of getting a decent education or a job, essentially robbed of any hope for the future.

As the nation's schools and infrastructure suffer from a lack of resources, right-wing politicians are enacting policies that lower the taxes of the rich and mega corporations. For the neoliberal elite, the collection of taxes constitutes a form of coercion and class warfare waged by the state against the rich. What is ironic in this argument is the startling fact that not only are the rich not taxed proportionately, but they even receive over $\$ 92$ billion in corporate subsidies. Even so, neoliberal ideology has resulted in widespread practices whereby "1paying taxes has devolved from a central social responsibility to a game of creative work-arounds." [5] There is more at stake here than untaxed wealth and revenue. As David Theo Goldberg points out, "Today, taxes are not so much the common contribution to cover the costs of social benefits and infrastructure relative to one's means, as they are a burden to be avoided."[6] Fierce debate over the issue of taxes is just one part of a larger project of hollowing out public institutions.

The outrage an ethically bankrupt neoliberalism voices against tax policies hardly conceals its loathing against any government which seeks to raise revenue in order to build and maintain public infrastructure, provide basic services for those who need them most, and develop investments such as a transportation system and schools that are not explicitly tied to the logic of the market. The battle being waged over crucial public resources is one that has dire political and educational consequences, especially for the poor and middle classes. One consequence is a vile form of class warfare that sacrifices the economic mobility and security of less wealthy citizens. There is also the fact that wealth buys and corrupts power, if not democracy itself. And this poisonous mix of wealth, power, and politics translates into an array of antidemocratic practices that creates an unhealthy society in every major index ranging from infant mortality rates to a dysfunctional electoral system.[7]

While it is evident that money controls elections in the United States, less apparent is the fact that it increasingly also controls the policies that shape public education.[8] One indicator of such corruption is that hedge fund managers now sit on school boards across the country doing everything in their power to eliminate public schools and punish unionized teachers who do not support charter schools. In New Jersey, hundreds of teachers have been sacked because of alleged budget deficits. Not only has Governor Christie used the deficit argument to fire teachers, he has also used it to break unions and balance the budget on the backs of students and teachers. How else to explain Christie's refusal to reinstitute the "millionaires' tax," or his craven support for lowering taxes for the top 25 hedge fund officers who in 2009 raked in \$25 billion_ enough to fund 658,000 entry level teachers? [9] 
In this conservative right-wing culture now dominating American politics, the role of public and higher education is to produce students who laud conformity, believe job training is more important than education, and view public values as irrelevant. If the Heritage Foundation, the Koch brothers, and Bill Gates-type billionaires have their way, students will no longer be educated for democratic citizenship. Even now, their education is too often reduced and justified through an appeal to fulfilling the need for human capital.[10] What is lost in this approach to schooling is what Noam Chomsky calls "creating creative and independent thought and inquiry, challenging perceived beliefs, exploring new horizons and forgetting external constraints." [11] At the same time, public schools and colleges are under assault not because they are failing (though some are), but because they remain one of the few public spheres left in which people can learn the knowledge and skills necessary to allow them to think critically and hold power and authority accountable.

Unfortunately, the lines between the corporate world and public and higher education are blurring more all the time, as modes of education (except for the elite) are reduced to what Peter Seybold calls a "corporate service station."'[12] At the heart of this imminent crisis regarding education are larger questions about the democratic ideals that have historically informed public and higher education, and have provided the formative culture necessary for a democracy to survive. The future of civic education, the role of educators as civic intellectuals, and education as a site of individual and collective empowerment hangs in the balance, as most aspects of education are now up for sale and increasingly being mined for private profit.

This current right-wing emphasis on low-level skills distracts the American public from examining the broader economic, political, and cultural forces that bear down on schools and undermine the purpose and meaning of education. The influence on schools of corporations, text book publishers, commercial industries, and the national security state are rendered invisible, as if schools and the practices in which they are engaged simply exist in a bubble. At work here is a dystopian view of schooling that displaces, infantilizes, and depoliticizes both students and large segments of the American public. Under the current regime of neoliberalism, education has been transformed into a private right rather than a public good. Students are now being educated to become consumers rather than thoughtful, critical citizens. Increasingly as public schools are put in the hands of for-profit corporations, hedge fund elites, and market-driven leadership, their only value is derived from their ability to turn a profit and produce compliant students eager to join the workforce.[13]

What is truly shocking about the current dismantling and disinvestment in public schooling is that those who advocate such changes are called the new educational reformers. They are not reformers at all. In fact, they are reactionaries and financial mercenaries and dystopian financial sleuths who are turning teaching into the practice of conformity and creating curricula driven by an anti-intellectual obsession with student test scores. This alleged reform movement is certain to turn students into active customers and passive subjects, increasingly unable to think critically about themselves and their relationship to the larger world. The poisonous virus of instrumentalism has infected public and higher education to the degree that some institutions have not only abandoned their public mandate, but even resemble repressive sites of containment devoid of critical learning, let alone soaring acts of curiosity and imagination.

As Diane Ravitch has pointed out, what is driving the current public school reform movement is a profoundly anti-intellectual project that promotes "1more testing, more privately managed schools, more deregulation, more firing of teachers, [and] more school closings." [14] At the level of higher education, the script is similar: defund higher education, impose corporate models of governance, purge the university of critical thinkers, turn faculty into a low-waged army of part-time workers, and allow corporate money and power to increasingly decide course content and determine which faculty get hired. As public values are replaced by corporate values, students become clients, faculty are deskilled and depoliticized, tuition rises, and more and more working-class and poor minority students are excluded from the benefits of higher education. There are no powerful and profound intellectual dramas in this view of schooling, just the muted rush to make schools another source of profit for finance capital.

Public and higher education are increasingly harnessed to the interests of corporations, a growing legion of bankers, billionaires, and hedge fund scoundrels, and the warfare state. One consequence is that many public schools, especially those occupied by poor minority youth, have become the new factories for dumbing down the curricula and turning teachers into what amounts to machine parts. At the same time, such schools have become militarized and provide a direct route for many youth into the prison-industrial complex or what has been called the school-toprison pipeline.[15] What is excised from the educational rhetoric of casino capitalism reform is the ideal of offering public school students a civic education that provides the capacities, knowledge, and skills that enable young people 
to speak, write, and act from a position of agency and empowerment. At the college level, students are dazzled by a blitz of commercialized spaces that now look like shopping malls, and in between classes they are entertained by a mammoth sports culture that is often as debasing as it is dangerous in its hypermasculinity, racism, and overt sexism.[16]

Privatization, commodification, militarization, and deregulation are the new guiding categories through which schools, teachers, classroom pedagogy, and students are defined. The current assaults on public and higher education are not new, but they are viler and more powerful than in the past. Crucial to any viable reform movement is the need to understand the historical context in which education has been transformed into an adjunct of corporate power as well as the current ways right-wing educational reform is operating within a broader play of power, ideology, and other social forces - which together are applying antidemocratic pressure to change the purpose of schooling and the practice of teaching itself. Making power visible is important, but it is only a first step in understanding how power actually works and how it might be challenged. Recognizing a challenge is not the same thing as overcoming it. Part of the significant task of reinvigorating civic education in the United States necessitates that educators anchor their own work in classrooms through projects that engage the promise of an unrealized democracy against its existing, often repressive, forms. And this is only the beginning of resistance that must struggle for broad-based social change.

Public and higher education, along with the pedagogical role of the larger culture, should be viewed as crucial to any viable notion of democracy, while the pedagogical practices they employ should be consistent with the ideal of the good society. Within the classroom, this means teaching more than the knowledge of traditional canons. In fact, teachers and students need to recognize that as a moral and a political practice, pedagogy is about the struggle over identity just as much as it is about learning and transmitting knowledge. At a time when censorship is rampant in public schools and dissent is viewed as a distraction or unpatriotic, the debate over whether we should view schools as political institutions might seem not only moot, but irrelevant. Yet, pedagogy remains a powerful mode of critical intervention, especially if one believes teachers have a responsibility to prepare students for being in the world in ways that will not only equip them for jobs but enable them to influence the larger political, ideological, and economic forces that bear down on their lives. Schooling is an inherently political and moral practice, because it is directive and actively legitimates particular values, forms of agency, and even what counts as knowledge.

One of the most notable features of contemporary conservative reform effort is the way in which it increasingly positions teachers as a liability, and in doing so accustoms them to modes of education that are as demeaning as they are deskilling. These reforms are not innocent and actually promote failure in the classroom. And when successful, they open the door for more public schools to be closed, provide another chance at busting the union, and allow such schools to be taken over by private and corporate interests. Under the influence of market-based pedagogies, public school teachers are the new welfare queens and are repeatedly subjected to what can only be described as repressive disciplinary measures in the school and an increasing chorus of verbal humiliation from politicians outside of the classroom. Academics do not fare any better and are often criticized for being too radical, for not working long hours, and for receiving cushy paychecks - a position at odds with the fact that over 70 percent of academic labor is now either part-time or on a non-tenure track.[17]

Teachers and academics are not only on the defensive in the neoliberal war on schools; they are also increasingly pressured to assume a more instrumental and mercenary role. Such conditions leave them with no time to be creative, use their imagination, work with other teachers, or develop classroom practices that are not wedded to teaching for the test and other demeaning empirical measures. Of course, the practice of disinvesting in public schools and higher education has a long history, but it has been around at least since the election of Ronald Reagan in the 1980s and has intensified in the new millennium. How else to explain that many states invest more in building prisons than educating students, especially those who are poor, disabled, and immersed in poverty? What are we to make of the fact that there are more black men in prison than in higher education in states such as Louisiana and California?[18] The right-wing makeover of public education has resulted in some states such as Texas banning critical thinking in their classrooms. In Arizona, legislation has been passed that eliminates all curricular material from the classroom that includes the histories of Mexican-Americans. These are the same states that want to tie the salaries of faculty in higher education to performance measures based on a neoliberal model of evaluation.

Fighting for democracy as an educational project means encouraging a culture of questioning in classrooms, one that explores both the strengths and the weaknesses of the current era. I think Zygmunt Bauman is right in arguing that "if there is no room for the idea of a wrong society, there is hardly much chance for the idea of a good society to be born, let alone make waves."[19] This notion of questioning is not simply about airing conflicting points of view, nor is it about substituting dogma for genuine dialogue and critical analysis. Rather, it is about a culture of 
questioning that brings ideas into the framework of public values and enables a broader engagement with the larger social order. At issue here are pedagogical practices that go beyond the search for knowledge to encourage taking responsibility for intervening in the world by connecting knowledge and power, and by developing learning and personal values into modes of commitment and social engagement. The relevant questions in this instance are what kind of future do our teachings presuppose? What forms of literacy and agency do we make available to our students through our pedagogical practices? How do we understand and incorporate in classroom pedagogies an ongoing search for equity and excellence, truth and justice, knowledge and commitment?

The broader project of addressing democratization as a pedagogical practice should be central to any worthwhile classroom teaching and learning experience. And this is a political project that encompasses both democratizing pedagogies and a pedagogy of democracy. Educators should begin with a vision of schooling as a democratic public sphere. Faced with growing ideological, political, and social impediments, educators must work together to figure out common goals and organize collectively to challenge the conditions that prevent them from engaging in a meaningful work both in and outside of the classroom. In other words, educators need to start with a project, not a method. They need to view themselves through the lens of civic responsibility and educate students in the best of those traditions and knowledge forms we have inherited from the past, but also prepare those students to act in the world as critically engaged agents responsible for our collective future.

Educators, if not already committed to democratization, need to be ready to consider how they will link their overall investment in education to modes of critique and collective action that address what it means to live in a democratic society while recognizing democratic societies are never too just or just enough. Such recognition perceives how any viable democratic society must constantly nurture the possibilities for self-critique, personal and collective agency, and forms of citizenship in which teachers and students play a fundamental role. Rather than be forced to participate in a pedagogy designed to raise institutional test scores and undermine forms of critical thinking, students must be involved in discussing, administering, and shaping the material relations of power and ideological forces that structure their everyday lives. Central to such an educational project is the ongoing struggle on the part of teachers to connect their pedagogical practices to the building of an inclusive and just democracy, which should be open to many forms, offers no political guarantees, and relies on the normative dimensions of politics as an ongoing process that never ends. Such a project is based on the realization that democracy and a democratic classroom involve ongoing exchange, questioning, and self-criticism that aspires each day to more closely envision and embody fairness, equality, and justice. It is precisely the open-ended and normative nature of such a project that provides a common ground for educators to share their resources through a diverse range of intellectual and practical pursuits while refusing to believe that struggles for greater justice in schools and in the broader society ever come to an end.

In order to connect teaching with the larger world so as to make pedagogy meaningful, critical, and transformative, educators will have to focus their work on important social issues that connect what is learned in the classroom to the larger society and the lives of their students. Such issues might include the ongoing destruction of the ecological biosphere, the current war against youth, the hegemony of neoliberal globalization, the growing influence of corporate culture on public schools, the widespread attack on the welfare system, the disproportionate rates of incarceration of people of color, the increasing gap between the rich and the poor, the rising burden of debt impacting college and university students, the spread of war globally, and the dangerous growth of the prisonindustrial complex.

In addition, educators should do more than create the conditions for critical learning for their students. They also need to responsibly assume the role of civic educators within broader social contexts and be willing to share their ideas with other educators and the wider public by making use of new media technologies. Communicating to a variety of public audiences suggests using opportunities for writing, public talks, and media interviews offered by the radio, Internet, alternative magazines, and the church pulpit, to name only a few. Such means of communication need to become public by crossing over into spheres and avenues of expression that speak to more general audiences in a language that is clear but not theoretically simplistic. Capitalizing on their role as intellectuals, educators can address the challenge of combining scholarship and commitment through the use of a vocabulary that is neither dull nor obtuse, while seeking to speak to a broad audience. More importantly, as teachers organize to assert the importance of their role and that of public schooling in a democracy, they can forge new alliances and connections to develop social movements that include and also expand beyond working with unions.

Educators also need to learn how to work collectively with other educators through a vast array of networks 
across a number of public spheres. This might mean sharing resources with educators in a variety of fields and sites, extending from other teachers to community workers and artists outside of the school. This also suggests that educators become more active and self-critical in addressing the ethical and political challenges of globalization. Public school teachers and higher education instructors need to unite in making a case for public and higher education. In the United States, they could at the very least make clear to a befuddled American public that the deficit theory regarding school cutbacks is a fraud.

There is plenty of money to provide quality education to every student in the United States—and this certainly holds true for the United Kingdom and Canada. As Salvatore Babones points out, "The problem isn't a lack of money. The problem is where the money is going."[20] The issue is not about the absence of funds as much as it is about where funds are being invested and how more revenue can be raised to support public education in the United States. The United States spends around $\$ 960$ billion on its wars and defense related projects. [21] In fact, the cost of war over a ten-year period 1 "will run at least $\$ 3.7$ trillion and could reach as high as $\$ 4.4$ trillion, according to the research project ' $€$ `Costs of War' by Brown University's Watson Institute for International Studies.' [22] As Babones argues, the crucial recognition here is that

research consistently shows that education spending creates more jobs per dollar than any other kind of government spending. A University of Massachusetts study ranked military spending worst of five major fiscal levers for job creation. The UMass study ranked education spending the best. A dollar spent on education creates more than twice as many jobs than a dollar spent on defense. Education spending also outperforms health care, clean energy and tax cuts as a mechanism for job creation.[23]

Surely, this budget could be trimmed appropriately to divert much needed funds to education given that a nation's highest priority should be investing in its children rather than in the production of organized violence. As capital, finance, trade, and culture become extraterritorial and increasingly removed from traditional political constraints, it becomes all the more pressing to put global networks and political organizations into play to contend with the reach and power of neoliberal globalization. Engaging in intellectual practices that offer the possibility of alliances and new forms of solidarity among public school teachers and cultural workers such as artists, writers, journalists, academics, and others who engage in forms of public pedagogy grounded in a democratic project represents a small, but important, step. Nothing less a critical mass will be sufficient to address the mammoth and unprecedented reach of global capitalism.

Educators also need to register and make visible their own subjective involvement in what they teach, how they shape classroom social relations, and how they defend their positions within institutions. This is especially crucial at a time when many institutions are legitimating educational processes based on narrow ideological interests and political exclusions rooted in a denial of social injustice and inequality. Teachers who recognize the ongoing operations of power both inside and outside of the classroom should make their own authority and classroom work the subject of critical analysis with students, and this must be done in ways that move beyond the narrow and often instrumentalized rhetoric of method, psychology, or private interests. Pedagogy in this instance becomes a moral and political discourse in which students are able to connect learning to social change, scholarship to commitment, and classroom knowledge to public life. Such a pedagogical task suggests that educators define intellectual practice as "part of an intricate web of morality, rigor and responsibility" [24] that enables them to speak with conviction, enter the public sphere in order to address important social problems, and demonstrate alternative models for what it means to bridge the gap between public education and the broader society.

Unfortunately, there are many academics, teachers, and right-wing pundits who argue that the classroom should be free of politics, and hence a space where matters of power, values, and social justice should not be addressed. The usual scornful accusation in this case is that teachers who believe in civic education indoctrinate their students. In this supposed ideologically pure world, pedagogy is reduced to a banal transmission of facts in which nothing controversial can be stated and teachers are forbidden to utter one word related to any of the major problems facing the larger society. Of course, this view of teaching is as much a flight from reality as it is an instance of irresponsible pedagogy. In contrast, one useful approach to embracing the classroom as a political site, but at the same time eschewing any form of indoctrination, is for educators to think through the distinction between a politicizing pedagogy, which insists wrongly that students think as we do, and a political pedagogy, which teaches students by example and through dialogue about the importance of power, social responsibility, and taking a stand (without standing still). Political pedagogy, unlike a dogmatic or indoctrinating pedagogy, embodies the principles of critical pedagogy through rigorously engaging the full range of ideas about an issue within a framework that enables 
students to move from moral purpose to purposeful action.

Political pedagogy offers the promise of nurturing students to think critically about their understanding of classroom knowledge and its relationship to the issue of social responsibility. It is also responsive to the challenge of educating students to engage the world critically in order to struggle for those political and economic conditions that make democratic participation in both schools and the larger society possible. Such a pedagogy affirms the experience of the social and the obligations it invokes regarding questions of responsibility and transformation. It does so by opening up for students important questions about power, knowledge, and what it means for them to critically engage the complex conditions impacting themselves and others. In addition, political pedagogy provides students with the knowledge and skills to analyze and work to overcome those social relations of oppression that make living unbearable for those who are poor, hungry, unemployed, deprived of adequate social services and viewed under the aegis of neoliberalism as largely disposable. What is important about this type of pedagogy is how responsibility is understood as both an ethical issue and a strategic act. Responsibility is not only a crucial element regarding what issues teachers address in a classroom; but is also embodied in their relationships with students, parents, and the wider society. Responsibility as a crucial part of any pedagogical practice suggests providing the connective tissue that enables students to raise issues about the consequences of their actions in the world and their behaviors toward others, and to analyze the relationship between knowledge and power and the social costs it often enacts. The emphasis on responsibility highlights the performative nature of pedagogy by raising questions about both the pedagogical relationship that teachers have with students, and about how ideas are situated in the public realm in order to highlight those practices and relationships that expand and deepen the possibilities of democracy.

Central here is the importance for educators to encourage students to connect knowledge and criticism as a precondition to becoming an agent of social change buttressed by a profound desire to overcome injustice and a spirited commitment to social action. Political education teaches students to take risks and challenge those with power. Likewise, it encourages students and teachers to be reflexive about how power is used in the classroom. Political education proposes that the role of the teacher as public intellectual is not to consolidate authority but to question and interrogate it, and that teachers and students should temper any reliance on authority with a sense of critical awareness and an acute willingness to hold it accountable for its consequences. Moreover, political education foregrounds education guided not by the imperatives of specialization and professionalization, but by goals designed to expand the possibilities of democracy. Linking education to modes of political agency is therefore part of a larger project to promote critical citizenship and address the ethical imperative to alleviate human suffering.

In contrast, politicizing education silences in the name of orthodoxy and imposes itself on students while undermining dialogue, deliberation, and critical engagement. Politicizing education is often grounded in a combination of self- righteousness and ideological purity that silences students as it enacts "correct" positions. Authority in this perspective rarely opens itself to self-criticism or for that matter to any criticism, especially from students. Politicizing education cannot decipher the distinction between critical teaching and pedagogical terrorism because its advocates have no sense of the difference between encouraging human agency and social responsibility, on the one hand, and molding students through taking an unquestioned ideological position and applying a sutured pedagogical script on the other. Politicizing education is more religious than secular, and more about training than educating. It harbors a great dislike for complicating issues, promoting critical dialogue, and generating a culture of questioning.

Education operates as a crucial site of power in the modern world. If teachers are truly concerned about safeguarding education, they will have to take seriously how pedagogy functions on local and global levels. It has a role to play in both securing and challenging how power is deployed, affirmed, and resisted within and outside of traditional discourses and cultural spheres. In a local context, critical pedagogy becomes an important theoretical tool for understanding the institutional conditions that place constraints on the production of knowledge, learning, academic labor, and democracy itself. Critical pedagogy also provides a discourse for engaging and challenging the production of social hierarchies, identities, and ideologies as they traverse local and national borders. In addition, pedagogy as a form of production and critique offers a discourse of possibility — a way of providing students with the opportunity to link understanding to commitment, and social transformation to seeking the greatest possible justice. Rejecting traditional, elitist notions of the intellectual, critical pedagogy and education encourage recognition of the vocation and contributions of teachers as intellectuals who undertake pedagogical and political work tempered by humility, a moral perspective on suffering, and the need to produce alternative visions and policies that go beyond a language of mere critique.

Positioning educators in public schools and higher education as public intellectuals has important implications that 
need to be connected to developing a new academic agenda, particularly at a time when neoliberal values increasingly guide social and educational policy. In opposition to the privatization, commodification, commercialization, and militarization of everything public, educators need to define public education as a resource vital to the democratic and civic life of the nation and larger global sphere. At the heart of such a task is the challenge for teachers, academics, cultural workers, and labor organizers to join together in opposition to the transformation of public education into commercial entities - in other words to resist what Bill Readings has called a consumer-oriented corporation more concerned about accounting than accountability.[25] As Bauman reminds us, schools are one of the few public spaces left where students can learn the "skills for citizen participation and effective political action. And where there is no [such] institution, there is no ' $€$ “citizenship' either." [26] Indeed, public education may be the last remaining site in which young people can engage in formal learning about the limits of commercial values, the skills of social citizenship, and how to deepen and expand the possibilities of collective agency and democratic life.

Defending education at all levels as a vital public sphere and a public good, rather than merely a private commodity, is necessary to develop and nourish the proper balance between democratic public spheres and commercial power, between identities founded on democratic principles and identities steeped in forms of competitive, self-interested individualism that celebrate selfishness, profit-making, and greed. Public education must be defended through intellectual work that self-consciously recalls the tension between the democratic imperatives and possibilities of public institutions and their everyday realization within a society dominated by market principles. If public education is to remain a site of critical thinking, collective work, and thoughtful dialogue, educators need to expand and resolutely defend how they view the meaning and purpose of their work with young people. As I have stressed repeatedly, academics, teachers, students, parents, community activists, and other socially concerned groups must provide the first line of defense in protecting public education as a resource vital to the moral life of the nation. And if public education is going to remain vital in its role, then it must continue to be accessible to people and communities whose resources, knowledge, and skills have often been viewed as marginal. This demands not only a renewed commitment to public values and educational ideals, but a concrete analysis of the neoliberal and other reactionary forces currently working to dismantle public education.

Fostering inclusive conditions that will achieve free quality education for everyone will begin first with the desire to build a powerful social movement. Such a project suggests that educators develop the vocabulary and practices for connecting progressive politics with effective modes of leadership. In part, this means providing students with the language, knowledge, and social relations to engage in the "art of translating individual problems into public issues, and common interests into individual rights and duties." [27] Leadership demands a politics and a pedagogy that refuses to separate individual problems and experience from public issues and social considerations. Within such a perspective, leadership displaces cynicism with hope, challenges the neoliberal notion that there are no alternatives with visions of a better society, and develops a pedagogy of commitment that puts into place modes of critical literacy in which competency and interpretation provide the basis for actually intervening in the world. Such leadership is responsive to the call to make the pedagogical more political by linking critical thought to collective action, human agency to social responsibility, and knowledge and power to a profound impatience with a status quo founded upon deep inequalities and injustices.

One of the increasingly crucial challenges faced by educators is rejecting the neoliberal collapse of the public into the private, and the rendering of all social problems as faults of the individual. The neoliberal obsession with privatization not only furthers a market-based ethic which reduces all relationships to the exchange of money and the accumulation of capital, it also depoliticizes politics itself and reframes public activity as utterly personal practices and utopias. Citizenship is consequently reduced to the act of buying and purchasing goods. Within this neoliberal discourse, all forms of solidarity, social behavior, and collective resistance disappear into the murky waters of a politics in which privatized pleasures and ready-made individual choices are organized solely on the basis of marketplace interests, values, and desires. This is a reactionary public pedagogy that cancels out all modes of social responsibility, commitment, and action. Its central ambition is the creation of atomized individuals who live in a moral coma, regress into a state of infantilism, and relate to others through a sheer Darwinist survival-of-the-fittest ethic. One of the major challenges now facing educators, especially in light of the current neoliberal attack on public workers, is to reclaim the language of social justice, democracy, and public life as the basis for rethinking how to name, theorize, and enact a new kind of education as well as more emancipatory notions of individual and social agency and collective struggle.

This challenge suggests, in part, developing new forms of social citizenship and civic education that have a purchase on people's everyday lives and struggles. Teachers and faculty bear an enormous responsibility in opposing 
neoliberalism — the most dangerous ideology of our time-by bringing democratic political culture back to life. Part of this effort demands creating new locations of struggle, vocabularies, and values that allow people in a wide variety of public spheres to become more than they are now, to question what it is they have become within existing institutional and social formations, and "to give some thought to their experiences so that they can transform their relations of subordination and oppression.”[28] One element of this struggle could take the form of resisting attacks on existing public spheres, such as schools, while creating new spaces in clubs, neighborhoods, bookstores, trade unions, alternative media, and other sites where dialogue and critical exchanges become possible. At the same time, challenging neoliberalism means protesting the ongoing reconfiguration of the state into the role of an enlarged police precinct designed to repress dissent, regulate immigrant populations, incarcerate youth who are considered disposable, and safeguard the interests of global investors. It also means supporting a shift in spending priorities in favor of young people and a sustainable democracy.

Revenue for investing in young people, social services, health care, crucial infrastructures, and the welfare state has not disappeared: it has simply been moved into other spending categories or used to benefit a small percentage of the population. For instance, U.S. military spending is far too bloated and supports a society organized for the mass production of violence. Such spending needs to be severely cut back without endangering the larger society. In addition, as John Cavanaugh has suggested, educators and others need to rally for policies that provide a small tax on stocks and derivatives, eliminate the use of overseas tax havens by the rich, and create tax policies in which the wealthy are taxed fairly.[29] Cavanagh estimates that the enactment of these three policies could produce as much as $\$ 330$ billion in revenue annually, enough to vastly improve the quality of education for all children through the United States.[30]

As many governments globally give up their role of providing social safety nets and regulating corporate greed, capital escapes beyond the reach of democratic control. This leaves marginalized individuals and groups at the mercy of their own meager resources to survive. Under such circumstances, it becomes difficult to create alternative public spheres that enable people to become effective agents of change. Under neoliberalism's reign of terror, public issues collapse into privatized discourses and a culture of personal confessions, avarice, and vacuous celebrity emerges to set the stage for depoliticizing public life and turning citizenship and governance into a form of consumerism. It gets worse. The rich and the powerful realize it is not in their own narrow interests to support public education, and many despise any real notion of democracy and the social good. They will do all in their power to control and defend their ideological and economic position as the dominant one ruling American society.

The growing attack on public education in the United States and elsewhere may say less about the reputed apathy of the populace than about the bankruptcy of old political languages and orthodoxies. The need for new vocabularies and visions for clarifying our intellectual, ethical and political projects is pressing, especially as these work to reinsert questions of agency and meaning back into politics and public life. In the absence of such a common language and the social formations and public spheres that make democracy and justice operative, politics becomes narcissistic and caters to the mood of widespread pessimism and the cathartic allure of the spectacle. In addition, public service and government intervention are sneered upon as either bureaucratic or a constraint upon individual freedom. Any attempt to give new life to a substantive democratic politics must therefore address the issue of how people learn to be political agents. It must inquire what kind of educational work is necessary and where this work can take place in order to enable people to use their full intellectual resources to provide a profound critique of existing institutions and undertake a struggle to make freedom and autonomy achievable for as many people as possible, in as wide a variety of spheres as possible. As engaged educators, we are required to understand more fully why the tools we used in the past feel awkward in the present, often failing to respond to problems now facing the American public and other people across the globe. More specifically, educators face the challenge posed by the failure of existing critical discourses to expose the growing gap between how society represents itself and how individuals experience themselves and others within society. The development of a common understanding and a critical orientation is a necessary precursor for engaging such representations and the oppressive social relationships they often legitimate.

Against neoliberalism, educators, students, and other concerned citizens face the task of providing a language of resistance and possibility, a language that embraces a militant utopianism while constantly being attentive to those forces that seek to turn such hope into a new slogan or to punish and dismiss those who dare to look beyond the horizon of the given. Hope is the affective and intellectual precondition for individual and social struggle. It is hope, not despair, motivating critique on the part of intellectuals in and outside of the academy who use the resources of 
theory to address pressing social problems. Hope is also at the root of the civic courage that translates critique into political practice. Hope as the desire for a future that offers more than the present becomes most acute when one's life can no longer be taken for granted. Only by holding on to both critique and hope in such contexts will resistance make concrete the possibility for transforming politics into an ethical space and a public act. And a better future than the one we now expect to unfold will require nothing less than confronting the flow of everyday experience and the weight of social suffering with the force of individual and collective resistance and the unending project of democratic social transformation.

There is a lot of talk among educators and the general public about the death of democratic schooling and the institutional support it provides for critical dialogue, nurturing the imagination, and creating a space of inclusiveness and engaged teaching. Given that educators and others now live in a democracy emptied of any principled meaning, the ability of human beings to imagine a more equitable and just world has become more difficult. Yet, I would hope critical educators, of all groups, would be the most vocal and militant in making clear that at the heart of any substantive democracy is the notion that learning should be used to expand the public good, create a culture of questioning, and promote democratic social change. Individual and social agency becomes meaningful when made part of a robust collective project that aims to "help us find our way to a more human future."[31] Under such circumstances, knowledge can be used for amplifying human freedom and promoting social justice, and not simply for private financial gain.

The diverse terrain of critical education and critical pedagogy offers insights for addressing these broader social issues. We would do well to learn as much as possible from the resources we have at hand in order to expand the meaning of the political and revitalize the pedagogical possibilities of cultural politics and democratic struggles. Pierre Bourdieu argued that intellectuals need to create new ways of doing politics by investing in political struggles through a permanent critique of abuses of authority and power, especially under the reign of neoliberalism. Bourdieu wanted educators to use their skills and knowledge to do more than inform academia and the classroom. He exhorted educators to combine scholarship with commitment and to "enter resolutely into sustained and vigorous exchange with the outside world (that is, especially with unions, grassroots organizations, and issue-oriented activist groups) instead of being content with waging the ' $€$ political' battles, at once intimate and ultimate, and always a bit unreal, of the scholastic universe." [32] At a time when our civil liberties are being destroyed and public institutions and goods all over the globe are under assault by the forces of a rapacious global capitalism, there is a concrete urgency on the horizon that demands not only the most engaged forms of political opposition on the part of teachers, but also new modes of resistance and collective struggle buttressed by rigorous intellectual work, social responsibility, and political courage.

The time has come for educators to distinguish caution from cowardice and recognize the need for addressing the dire crisis public education is now facing. As Jacques Derrida reminded us, democracy "demands the most concrete urgency...because as a concept it makes visible the promise of democracy, that which is to come."'[33] We have seen glimpses of such a promise among those brave students and workers who have demonstrated in Montreal, Paris, Athens, Toronto, and many other cities across the globe. Teachers can learn from such struggles by turning the colleges and public schools into vibrant critical sites of learning and unconditional spheres of pedagogical and political resistance. The power of the existing dominant order does not merely reside in the economic or in material relations of power, but also in the realm of ideas and culture. This is why educators as engaged intellectuals must take sides, speak out, and welcome the hard pedagogical work of debunking corporate culture's assault on teaching and learning, while also orienting their teaching for social change and connecting classroom learning to public life. At the very least, educators can examine the operations of power in their own classrooms and provide a safe space for students to address a variety of important issues ranging from poverty to crimes against humanity.

Assuming the role of public intellectual suggests being a provocateur in the classroom. It means asking hard questions, listening carefully to what students have to say, and teaching against the grain. It also means stepping out of the classroom and working with others to create public spaces where it becomes possible not only to "shift the way people think about the moment, but potentially to energize them to do something differently in that moment." [34] Students and others should be encouraged to link their critical imagination with the possibility of activism in the public sphere. This is, of course, a small step, but a necessary one if we do not want a future that repeats or sustains the worst afflictions of our present, or subsumes any remaining public spheres within the workings of dominant power. It is time for educators to mobilize their energies by breaking down the illusion of unanimity that dominant power propagates while working diligently, tirelessly, and collectively to reclaim the promises of a truly global, democratic future.

There is no room for a dystopian pedagogy in a democratic society because this form of pedagogy destroys the 
foundation of critical engagement, hope, and resistance necessary for a democratic formative culture-one equipped to provide people with a full range of knowledge, skills, and values that can support ongoing collective struggles for democratization. In light of the current neoliberal assault on all democratic public spheres, along with the urgency of the problems faced by those marginalized by class, race, age, and sexual orientation, I think it is all the more crucial to take seriously the challenge of Derrida's provocation that "we must do and think the impossible. If only the possible happened, nothing more would happen. If I only I did what I can do, I wouldn't do anything." [35] We may live in dark times, as Hannah Arendt reminded us, but history is open and the space of the possible is larger than the one on display.

\section{Endnotes}

1. See, for example, Jeff Madrick, Age of Greed: The Triumph of Finance and the Decline of America, 1970 to the Present (New York: Vintage, 2011); Charles Ferguson, Predator Nation (New York: Crown Business, 2012); Henry A. Giroux, Zombie Politics in the Age of Casino Capitalism (New York: Peter Lang, 2010).

2. David Theo Goldberg, "The Taxing Terms of the GOP Plan Invite Class Carnage," Truthout (September 20, 2012). Online: http://truth-out.org/news/item/11630the-taxing-terms-of-the-gop-plan-invite-class-carnage

3. I have taken up the attack on higher education in a number of books. See, for example, Henry A. Giroux and Susan Searls Giroux, Take Back Higher Education (New York: Palgrave Press, 2004) and The University in Chains (Boulder: Paradigm, 2009).

4. David Theo Goldberg, "The University We Are For," Huffington Post (November 28, 2011). Online: http:// www.huffingtonpost.com/david-theo-goldberg/ university-california-protests_b_1106234.html

5. Goldberg, "The Taxing Terms of the GOP."

6. Ibid.

7. See Joseph E. Stiglitz, The Price of Inequality (New York: W.W. Norton, 2012).

8. Michael Sandel, What Money Can't Buy (New York: FSG, 2012).

9. Les Leopold, "Hey Dad, Why Does This Country Protect Billionaires, and Not Teachers?" AlterNet (May 5, 2010). Online: ttp://www.alternet.org/ story/146738/\%22hey_dad,_why_does_this_country_ protect_billionaires,_and_not_teachers $\% 22$

10. David Glenn, "Public Higher Education Is '€^Eroding From All Sides,' Warns Political Scientists," Chronicle of Higher Education (September 2, 2010). Online: http://chronicle.com/article/Public-HigherEducation-Is/124292/
11. Noam Chomsky, "Public Education under Massive Corporate Assault-What's Next? Alternet (August 5, 2011). Online: http://www.alternet.org/ story/151921/chomsky\%3A_public_education _ under_massive_corporate_assault_\%E2\%80\%94_ what's_next

12. Peter Seybold, "The Struggle against the Corporate Takeover of the University," Socialism and Democracy 22:1 (March 2008), pp1-2.

13. Nancy Hass, "Scholarly Investments," New York Times (December 6, 2009), pp. ST1, 10.

14. Diane Ravitch, "Two Visions for Chicago's Schools," Common Dreams (September 14, 2012). Online: https://www.commondreams.org/view/2012/09/143 ?print

15. See Sadhbh Walshe, 1"US Education Orientation for Minorities: The School-to-Prison Pipeline," The Guardian (August 31, 2012). Online: http://www. guardian.co.uk/commentisfree/2012/aug/31/useducation-orientation-minorities. See also, Henry A. Giroux, Youth in a Suspect Society (New York: Palgrave, 2009); and the ACLU Report, Locating the School-to-Prison Pipeline, online: http://www.aclu. org/racial-justice/school-prison-pipeline

16. See: Henry A. Giroux1 and Susan Searls Giroux, "Scandalous Politics: Penn State and the Return of the Repressed in Higher Education," JAC (in press).

17. AFT Hither Education, "A National Survey of Part-Time/Adjunct Faculty," American Academic Vol. 2. (March 2010). Online: http://www.aft.org/pdfs/ highered/aa_partimefaculty0310.pdf

18. Charles M. Blow, "Plantations, Prisons and Profits," New York Times (May 25, 2012). Online: http://www. nytimes.com/2012/05/26/opinion/blow-plantationsprisons-and-profits.html. For a detailed analysis of the racist prison-industrial complex, see 1Angela Y. Davis, Abolition Democracy: Beyond Empire, Prisons, 
and Torture (New York: Seven Stories Press, 2005); 1Michelle Brown, The Culture of Punishment: Prison, Society and Spectacle (New York: New York University Press, 2009); Michelle Alexander, The New Jim Crow (New York: Free Press, 2012).

19. Zygmunt Bauman, Society under Siege (Malden, MA: Blackwell: 2002), p. 170.

20. Salvatore Babones, "To End the Jobs Recession, Invest an Extra \$20 Billion in Public Education," Truthout (August 21, 2012). Online: http://truth-out. org/opinion/item/11031-to-end-the-jobs-recessioninvest-an-extra-\$20-billion-in-public-education

21. FT's Lex blog, "U.S. Defense Spending: What's the Real Figure?" The Globe and Mail (May 28, 2012). Online: http://www.theglobeandmail.com/report-onbusiness/international-business/us-defence-spendingwhats-the-real-figure/article 4217831 /

22. Daniel Trotta, "Cost of War $\$ 3.7$ Trillion and Counting, 258,000 Dead," Reuters (June 28, 2011). Online: http://uk.reuters.com/article/2011/06/29/ukusa-war-idUKTRE75S76R20110629

23. Babones, "To End the Jobs Recession."

24. Arundhati Roy, Power Politics (Cambridge, Mass.: South End Press, 2001), p. 6.

25. Bill Readings, The University in Ruins (Cambridge, Mass.: Harvard University Press, 1996), pp. 11, 18.

26. Zygmunt Bauman, In Search of Politics (Stanford: Stanford University Press, 1999), p. 170.
27. Zygmunt Bauman, Society under Siege (Malden, MA: Blackwell: 2002), p. 70.

28. Lynn Worsham and Gary A. Olson, "Rethinking Political Community: Chantal Mouffe's Liberal Socialism," Journal of Composition Theory 19:2 (1999), p. 178.

29. John Cavanagh, "Seven Ways to End the Deficit (without Throwing Grandma under the Bus)," Yes! Magazine (September 7, 2012). Online: http://www. yesmagazine.org/new-economy/seven-ways-to-endthe-deficit-without-throwing-grandma-under-the-bus

30. Ibid.

31. Noam Chomsky, "Paths Taken, Tasks Ahead," Profession (2000), p. 34.

32. Pierre Bourdieu, "For a Scholarship of Commitment," Profession (2000), p. 44.

33. Jacques Derrida, "Intellectual Courage: An Interview," Trans. Peter Krapp, Culture Machine, Vol. 2 (2000), p. 9.

34. Lani Guinier and Anna Deavere Smith, "Rethinking Power, Rethinking Theater: A Conversation between Lani Guinier and Anna Deavere Smith," Theater 31:3 (Winter 2002), pp. 34-35.

35. Jacques Derrida, "No One Is Innocent: A Discussion with Jacques about Philosophy in the Face of Terror," The Information Technology, War and Peace Project, p. 2. Online: http://www.watsoninstitute.org/ infopeace/911/derrida_innocence.html 